\title{
Treatment of cytomegalovirus retinitis with an intraocular sustained-release ganciclovir implant
}

C. Muccioli and R. Belfort Jr.
Departamento de O ftalmologia, Escola Paulista de Medicina, Universidade Federal de São Paulo, São Paulo, SP, Brasil

\section{Correspondence}

C. Muccioli

Rua Botucatu, 822

04023-062 São Paulo, SP

Brasil

Fax: + 55-11-573-4002

E-mail: eyebr@webmail.epm.br

Publication supported by FAPESP.

Received March 24, 1999

Accepted March 8, 2000

\section{Abstract}

The objective of this prospective study was to evaluate the efficacy and complications of the use of an intraocular sustained-release ganciclovir implant for the treatment of active cytomegalovirus (CMV) retinitis in AIDS patients. Thirty-nine eyes of 26 patients were submitted to ocular surgery. All patients underwent complete ocular examination before and after surgery. The surgical procedure was always done under local anesthesia using the same technique. The mean time for the surgical procedure was $20 \mathrm{~min}$ (range, 15 to $30 \mathrm{~min}$ ). The average follow-up period was 3.7 months. Of all patient, only 4 presented recurrence of retinitis after $8,8,9$ and 2 months, respectively. Three of them received a successful second implant. All 39 eyes of the 26 patients presented healing of retinitis as shown by clinical improvement evaluated by indirect binocular ophthalmoscopy and retinography. Retinitis healed within a period of 4 to 6 weeks in all patients, with clinical regression signs from the third week on. Six (15.4\%) eyes developed retinal detachment. None of the patients developed CMV retinitis in the contralateral eye. The intraocular implant proved to be effective in controlling the progression of retinitis for a period of up to 8 months even in patients for whom systemic therapy with either ganciclovir or foscarnet or both had failed. The intraocular sustained-release ganciclovir implant proved to be a safe new procedure for the treatment of CMV retinitis, avoiding the systemic side effects caused by the intravenous medications and improving the quality of life of the patients.

\section{Introduction}

Acquired immunodeficiency syndrome (AIDS) is a fatal disease caused by the human immunodeficiency virus (HIV), characterized by lymphocytopenia, development of secondary infections and tumors (1). In Brazil, according to the survey of the 1998 Epidemiology Bulletin of the Ministry of Health (National Program of Sexually Transmis-

\author{
Key words \\ - Cytomegalovirus \\ - Retinitis \\ - Intraocular inflammation \\ - AIDS \\ - Uveitis
}

sible Diseases/AIDS) for the period from 1980 to 1998 , a total of 150,000 cases of AIDS were reported, including adults, adolescents and children under 15 years (2). The survival of HIV-infected patients is increasing, mostly due to the use of antiretroviral therapy and better control of AIDS-related opportunistic infections (3). In 1992, the Centers for Disease Control (CDC) revised its classification system for HIV infection, 
emphasizing the importance of CD4 cell count in order to categorize the HIV-related clinical conditions. The system is based on the presence of HIV-specific positive serology and on three clinical categories and three CD4 values (4). HIV virulence is the result of its debilitating effect on the immune system, rendering the patient vulnerable to infections and malignancies (5). One example of these infections is cytomegalovirus (CMV) retinitis, a late stage AIDS manifestation which develops in patients with severe immunodeficiency (6). This opportunistic infection is an indicator of a disease fulfilling CDC criteria for AIDS diagnosis. Before 1982, CMV retinitis was a very rare disease occurring usually after chemotherapy as a consequence of immunological depression (7). CMV infection in immunocompetent patients seldom leads to ocular impairment, with only two reports in the literature (8). With the advent of the AIDS pandemic, CMV retinitis has become one of the most important causes of infectious retinitis all over the world $(9,10)$. Research on CMV and related diseases was first described in 1921 by Goodpasture and Talbot (11) who coined the term cytomegaly to describe the presence of large mononuclear inclusions found at autopsy in several organs of children $(11,12)$.

The spectrum of diseases known to be caused by CMV expanded in 1965 when Klemola and Kaariainen (13) described the mononucleosis-like CMV infection syndrome in adult immunocompetent patients. During the following years CMV became more important because it was a frequent opportunistic pathogen in the immunodepressed. The increasing number of organ and medulla transplants and an increase in the use of immunosuppressants were associated with the presence of pneumonitis, colitis, hepatitis, encephalitis, retinitis and other diseases due to CMV in these patients. Since 1981 CMV has been recognized as the most important opportunistic infection in AIDS patients (14).
The first published series of AIDS-related ocular disease already described CMV retinitis as a complication of the syndrome (15-17). In AIDS patients, CMV primarily infects the retina, but some papers have reported infection of other ocular structures such as cornea, conjunctiva, iris and ciliary body (18). CMV retinitis is the most common ocular infection in AIDS patients and the main cause of their blindness, affecting approximately 30 to $50 \%$ of these patients in different countries, including Brazil $(19,20)$. The only risk factor clearly associated with the development of CMV retinitis in HIVinfected patients is the low number of T CD4 lymphocytes. Retinitis almost always appears at levels below 100 cells $/ \mathrm{mm}^{3}$ and the risk is higher when the number is below 50 cells/ $\mathrm{mm}^{3}(21,22)$. The diagnosis of CMV retinitis is based on the clinical aspect of the lesion but there are atypical cases requiring laboratory studies to establish the diagnosis $(23,24)$.

Pannuti et al. (25) in 1996 used cell culture and the antigenemia test for CMV in patients with AIDS and CMV retinitis without previous treatment and concluded that patients with AIDS and active CMV had active replication of peripheral leukocytes and could benefit from this auxiliary exam in their treatment.

The retinitis is necrotizing, with whiteyellowish areas, varying degrees of hemorrhage and vasculitis. Anterior chamber and vitreous inflammation is usually light without formation of posterior synechiae. Retinitis may be uni- or bilateral, but cases presenting with unilateral disease have a high risk of second eye involvement, probably due to hematogenic dissemination. Spontaneous remission is extremely rare and possibly related to improvement in immunity (26).

The first, classical pattern of CMV retinitis, called hemorrhagic, is characterized by retinal areas with a granular, whitish and hemorrhagic aspect, usually with lesions close to the vascular arcades or to the optic nerve, and subretinal exudation. The retinal 
vessels in the necrotic area may be sheathed by vasculitis and consequently present retinal vascular, especially venous, occlusions. Central healing of the lesions occurs after necrosis, leading to atrophy of the retina and choroid (27).

The second pattern of retinitis is the granular or atypical one. The retina shows granular focal infiltrates which increase linearly and slowly, leaving areas of retinal destruction with an atrophic retinal pigmentary epithelium allowing to observe details of the choroid. Retinal hemorrhages and vitreous cells usually are absent on biomicroscopy in this retinitis pattern (14).

The third pattern, more rarely observed, associated or not with the classical hemorrhagic form is characterized by severe vasculitis, with intense sheathing shown by arteries and veins, resembling frosted branch angiitis (14).

Complications of retinitis include retinal detachment which occurs in 17 to $34 \%$ of the patients. Posterior vitrectomy, followed by intraocular injection of silicone oil, and endolaser application is the present treatment technique $(28,29)$.

Before 1985, patients with CMV retinitis had a very poor visual prognosis. Several pharmacological treatments, including vidarabine, acyclovir, alpha-interferon and interleukin-2 had been tried without success (30). Since 1989, with the release of ganciclovir for intravenous use in the US, the natural history of the disease has changed. Foscarnet, in 1991, was approved for intravenous use in the US and more recently, in 1996, another antiviral, called cidofovir, was approved. To date, only these 3 drugs have been approved by the Food and Drug Administration (FDA - USA) and are available for treatment of CMV retinitis (31). All are virostatic and, when applied intravenously, cause important side effects: neutropenia by ganciclovir and renal toxicity by foscarnet and cidofovir. Treatment with any of the drugs should initially use a loading dose for
2 to 3 weeks and then a maintenance dose for the rest of the life of the patient, leading to a significant worsening in the quality of life, the patient not being able to work and to carry out the usual activities of everyday life (14,31).

Ganciclovir activity against human CMV primarily results in inhibition of viral DNA synthesis. It competitively inhibits dGTP incorporation into DNA and is also directly incorporated into viral DNA, blocking the completion of its formation (14). Maintenance therapy with ganciclovir is necessary to control progression of the disease. Even in patients under maintenance therapy, retinitis may progress, often requiring reinduction (14).

Due to the potentially irreversible side effects, or to the absence of response to intravenous treatment, several studies were performed using intravitreous ganciclovir injections for local treatment (31). Local therapies are efficient in CMV retinitis treatment, but their relative risks and benefits, when compared with those of intravenous therapy, need to be clarified. Local therapy will be an important treatment modality for some selected patients with CMV retinitis. Indications include patients who are unable to receive intravenous therapy and as a supplement in patients whose retinal disease is not completely controlled using maximum tolerated systemic medication. Perhaps the best use of local therapy is in association with oral forms (30).

The literature started to report the experience with the use of ganciclovir implants for the treatment of CMV retinitis in 1992. Such implants consisted of a polymer base with a platform allowing programmed release of the drug, which was placed surgically in the posterior ocular chamber (32). Anand et al. (33) in 1993 reported their experience with these implants in a sample of 22 patients ( 30 eyes). No severe complications associated with the implant were observed, except for one patient who developed endophthalmitis. 
The authors concluded that this was an efficient form to treat CMV retinitis.

In the anatomopathological study, Anand et al. (34) observed that the intraocular implant was efficient in retinitis control and that the clinical and pathological results were similar to those observed in eyes of patients who were treated with intravenous ganciclovir. In addition, they observed the absence of side effects or local toxicity.

In 1994, results of a randomized clinical study carried out in the US using the same type of implant and the same surgical technique were published, confirming the results of former studies and proving the efficacy of this therapeutic procedure. The study included 26 patients (30 eyes) with CMV retinitis divided into two groups: one receiving immediate treatment and the other, late treatment. All patients were treated with ganciclovir implants with a release rate of $1 \mu \mathrm{g} / \mathrm{h}$. In this series of patients there was clinical improvement and complete healing of the lesions, confirming the results of former studies and showing that this is an efficient therapeutic modality for the treatment of $\mathrm{CMV}$ retinitis (35).

The purpose of the present study was to analyze the efficacy of intraocular implants of sustained release of ganciclovir for the treatment of CMV retinitis in AIDS patients and their complications.

\section{Patients, Material and Methods}

A clinical prospective study on 39 eyes of 26 patients with AIDS and with a clinical diagnosis of CMV retinitis was performed over a period of one year.

The protocol was approved by the Medical Ethics Committee of Universidade Federal de São Paulo (Escola Paulista de Medicina) and Hospital São Paulo, which authorized the use of an experimental drug, permitted by the Ministry of Health, according to a Resolution of the National Health Council.
Three of the 26 patients $(11.5 \%)$ were submitted to placement of two implants in the same eye. AIDS diagnosis was based on the definition of AIDS, as revised by the CDC (4). The patients were referred by physicians, from different institutions. All patients were submitted to clinical and serological evaluation before the study and throughout the postoperative period, at monthly intervals.

Inclusion criteria were: AIDS diagnosis according to CDC criteria, active CMV retinitis in the eye to be treated, clinical worsening of CMV retinitis after intravenous treatment with ganciclovir or foscarnet, signed written consent form, and availability to appear for the returns required by the protocol.

Exclusion criteria were: absence of previous intravenous treatment with ganciclovir or foscarnet, retinal detachment in the eye to be treated, previous eye disease, hypersensitivity to ganciclovir or foscarnet, pregnancy, lactation, and indication for intravenous use of ganciclovir or foscarnet.

During each visit, all patients were submitted to a complete ophthalmological examination which consisted of measurement of best corrected visual acuity according to Snellen's chart, ectoscopy, biomicroscopy, applanation tonometry, and indirect binocular ophthalmoscopy under drug-induced mydriasis.

Specific examinations, such as retinography, angiofluoresceinography, ultrasonography and ultrasound biometry were performed when required.

The diagnosis of CMV retinitis was established and the response to treatment was evaluated through ophthalmoscopic examination. The following parameters were studied: the best corrected visual acuity, number, localization and extension of the lesions. Localization and progression of the lesions were determined using the retinal area scheme standardized by Holland et al. (36), which divides the retina into three zones: (scheme 1) zone 1: retinal area located within 3,000 
$\mu \mathrm{m}$ of the fovea or $1,500 \mu \mathrm{m}$ from the optic nerve; zone 2: retinal area extending from the border of zone 1 to the anterior border of the vorticose veins; zone 3: retinal area extending from the border of zone 2 to the ora serrata. The extension of the lesion was estimated using the following semiquantitative evaluation: less than $10 \%$ of the retina involved, 11 to $25 \%$ of the retina involved, 26 to $50 \%$ of the retina involved, over $50 \%$ of the retina involved. As reference, the macula was considered to be approximately $5 \%$ of the whole area of the retina.

Worsening was defined as progression, increase in number and/or area of CMV retinitis lesions according to examination of the retina by two ophthalmologists. Improvement was defined as increased granular aspect of the involved retina, mainly at the border and the progressive demarcation and interruption of the area of lesion growth.

Sustained-release ganciclovir implants (Vitrasert, Chiron Vision, Claremont, NH, USA) placed in the vitreous cavity consisted of a polymer with a drug release system. They contained approximately $6 \mathrm{mg}$ of ganciclovir in a $1-\mathrm{mm}$ thick tablet measuring $2.5 \mathrm{~mm}$ in diameter covered on all sides with $30 \mu 110 \%$ polyvinyl alcohol (PVA) (permeable polymer) and wrapped in a discontinuous, prepressed film of ethylenevinyl acetate (EVA) (impermeable polymer). The whole structure was covered again with PVA. The EVA cover was impermeable to ganciclovir while the semipermeable PVA cover allowed diffusion of the drug. The implants were then wrapped again in a $3-\mathrm{mm} 10 \%$ PVA disk, sterilized with ethylene oxide and placed in individual sterile packages. The expected rate of release was $1 \mu \mathrm{g} / \mathrm{h}$.

Peribulbar anesthesia was performed using approximately $2 \mathrm{ml} \%$ lidocaine (Xylocaine $^{\circledR}$ ) with a vasoconstrictor and $2 \mathrm{ml} 0.75 \%$ bupivacaine $\left(\right.$ Marcaine ${ }^{\circledR}$ ) without a vasoconstrictor. A limbic conjunctival incision in the lower temporal quadrant was made, with hemostasis of episcleral and conjuncti- val vessels. The intravitreous implant was prepared, and a $6.0-\mathrm{mm}$ scleral incision was made $4 \mathrm{~mm}$ from and parallel to the limbus, exposing the choroid. The implant was sutured to the sclera with a single suture of 9.0 mononylon Ethicon ${ }^{\circledR}$. External vitrectomy was performed and the implant was placed in the vitreous cavity under microscopic control to ascertain its correct position. The incision was closed with continuous Ethicon ${ }^{\circledR}$ mononylon 9.0 sutures. The conjunctiva was then sutured and $10 \mathrm{mg}$ gentamicin and $1 \mathrm{mg}$ dexamethasone were injected subconjunctivally.

Surgeries lasted 15 to $30 \mathrm{~min}$, with a mean of 20 min, without any transoperative complication. Adequate position of the implant was confirmed by direct observation through the dilated pupil by slight scleral depression.

The patients were discharged immediately after being liberated by the anesthesiologist.

The eye was occluded for 12 to $24 \mathrm{~h}$. The patient took an antibiotic and a corticoid 4 times daily for 2 weeks and a topic mydriatic preparation every $12 \mathrm{~h}$ for 3 days.

Postoperative evaluations were made on days $1,3,7,15,30$ and monthly after the first month for the next 12 months.

\section{Results}

The age of the patients ranged from 26 to 47 years, with a mean of 35.2 years. Three patients $(11.5 \%)$ were females and 23 $(88.5 \%)$ males. Follow-up ranged from 30 days to 9 months (date of the last eye examination), with a mean of 3.7 months. In 8 eyes of 7 patients (18\%) this time was 6 months or longer.

Of the 3 patients who developed extraocular CMV, one had intestinal CMV, one CMV pneumonia and one ascending CMV myelitis. All were referred for intraocular implant placement because they presented severe neutropenia and contraindication for intrave- 
nous treatment with the dose required for retinitis treatment.

Of the total of 39 operated eyes, $6(15.4 \%)$ presented less than $10 \%$ retinal involvement, 18 (46.1\%) between 10 and 24\%, 11 (28.2\%) between 25 and $49 \%$, and $4(10.3 \%)$ over $50 \%$. Twelve eyes (30.8\%) presented retinal lesion located in zone $1,8(20.5 \%)$ in zone 2 , $4(10.3 \%)$ in zone $3,2(5.1 \%)$ in zones 1 and 2, $6(15.4 \%)$ in zones 2 and 3 , and $7(17.9 \%)$ in zones 1, 2 and 3 (Table 1).

Twenty patients $(77 \%)$ presented bilateral retinitis and $6(23 \%)$ unilateral retinitis. Of those who presented bilateral retinitis, 10 $(50 \%)$ had both eyes surgically treated and $10(50 \%)$ received the implant in only one eye. Although presenting CMV retinitis in both eyes, they received the implant in only one eye because of the following situations in the fellow eye: visual acuity limited to light perception, optic atrophy, retinal detachment and blindness. In 3 patients (11.5\%) a second implant was placed in the same eye.

No patient developed intraocular infection or severe uveitis. Some eyes presented 1 or $2+$ cells in the anterior chamber during the first weeks after surgery, returning to the situation before surgery after 1 or 2 weeks. Indirect ophthalmoscopy during the first weeks showed absence of detachment of the retina or choroid.

Of all patients, only 4 presented retinitis relapse after $8,8,9$ and 2 months, respectively. Three of them received a successful second implant. One patient did not receive the second implant because he developed very severe CMV retinitis and visual acuity of no light perception. All 39 eyes of the 26 patients presented healing of the retinitis expressed by clinical improvement as evaluated by indirect binocular ophthalmoscopy and as confirmed by retinography. Retinitis healed within 4 to 6 weeks in all patients, with clinical signs of regression from the third week on. Of the 39 operated eyes, 13 $(33.3 \%)$ maintained the same visual acuity from the preoperative to the last examina- tion, 13 eyes (33.3\%) showed improved visual acuity, and 13 eyes (33.3\%) showed a worse visual acuity (Table 2 ).

Of the eyes with improved vision, $7(18 \%)$ improved by 2 or more lines of visual acuity and $6(15.4 \%)$ improved by 1 line. Of those who had worse vision, $6(15.4 \%)$ worsened by 1 line and 7 worsened by 2 or more lines of visual acuity. Causes of vision worsening were retinal detachment, central nervous system involvement (neurotoxoplasmosis and neurocryptococcosis), and severe and abrupt recurrence.

Mean preoperative ocular pressure was $10.4 \mathrm{mmHg}$ (SD 1.5) and mean 30-day postoperative ocular pressure was $11.2 \mathrm{mmHg}$ (SD 2.9). No pressure below $6 \mathrm{mmHg}$, above $20 \mathrm{mmHg}$ or chronic ocular hypotonia was observed.

Six eyes (15.4\%) of 6 patients (23\%) presented retinal detachment, three of them during the third month after surgery (patients number 2, 7 and 26). The others developed it during the first (patient 18), second (patient 11) and fourth (patient 14) month. The areas of retinitis involvement of these patients were zone 3 in 4 eyes (patients 2, 7, 11, and 26) and zone 1, 2 and 3 in 2 eyes (patients 14 and 18).

The patients were submitted to posterior vitrectomy, with retinopexy, endophotocoagulation and silicone oil injection. All patients submitted to retinopexy progressed to cured retinal detachment, without relapse of CMV retinitis or need for implant removal. No patient developed CMV retinitis in the contralateral eye.

Three eyes of three patients with relapses of CMV retinitis received a second implant using the same technique and without complications. The implants were placed in the nasal quadrant and no complications occurred. The time before relapse was 8,8 and 9 months for patients 6,7 and 10 , respectively.

Three patients (11.2\%) developed extraocular CMV and were treated with main- 
Table 1 - Patient, eye, pre-operative visual acuity, presence of cytomegalovirus (CMV) retinitis and retinal involvement.

$\mathrm{RE}=$ Right eye; $\mathrm{LE}=$ left eye; visual acuity pre-RE = pre-operative visual acuity in the RE; visual acuity pre-LE $=$ pre-operative visual acuity in the LE; Zone RE = retinal involvement in RE; Zone $L E=$ retinal involvement in $\mathrm{LE} ;$ Area \% RE = percentage of retinal involvement in RE; Area \% LE = percentage of retinal involvement in LE; CF $1 \mathrm{~m}, 2 \mathrm{~m}$ and $3 \mathrm{~m}$ = visual acuity of finger counts at 1, 2 or $3 \mathrm{~m}$, respectively; $\mathrm{HM}=$ visual acuity of hand movements; N/LP = visual acuity of no light perception; LP = visual acuity of light perception.

\begin{tabular}{|c|c|c|c|c|c|c|c|c|c|}
\hline \multicolumn{2}{|c|}{ Patient/eye } & \multicolumn{2}{|c|}{ Visual acuity } & \multicolumn{2}{|c|}{$\mathrm{CMV}$ retinitis } & \multicolumn{2}{|c|}{ Zone } & \multicolumn{2}{|c|}{ Area } \\
\hline & & pre-RE & pre-LE & RE & LE & $\mathrm{RE}$ & LE & $\% R E$ & $\%$ LE \\
\hline 1 & RE & CF $1 \mathrm{~m}$ & LP & Yes & Yes & $1,2,3$ & $1,2,3$ & $>50$ & $>50$ \\
\hline 2 & RE & $20 / 40$ & $20 / 20$ & Yes & No & 2,3 & - & $25-49$ & - \\
\hline 3 & $\begin{array}{l}\text { LE } \\
\text { RE }\end{array}$ & $\begin{array}{l}20 / 25 \\
20 / 25\end{array}$ & $\begin{array}{l}20 / 20 \\
20 / 20\end{array}$ & $\begin{array}{l}\text { Yes } \\
\text { Yes }\end{array}$ & $\begin{array}{l}\text { Yes } \\
\text { Yes }\end{array}$ & $\begin{array}{l}2 \\
2\end{array}$ & $\begin{array}{l}2 \\
2\end{array}$ & $\begin{array}{l}10-24 \\
10-24\end{array}$ & $\begin{array}{l}10-24 \\
10-24\end{array}$ \\
\hline 4 & $\begin{array}{l}\text { LE } \\
\text { RE }\end{array}$ & $\begin{array}{l}20 / 25 \\
20 / 25\end{array}$ & $\begin{array}{l}20 / 25 \\
20 / 25\end{array}$ & $\begin{array}{l}\text { Yes } \\
\text { Yes }\end{array}$ & $\begin{array}{l}\text { Yes } \\
\text { Yes }\end{array}$ & $\begin{array}{l}3 \\
3\end{array}$ & $\begin{array}{l}3 \\
3\end{array}$ & $\begin{array}{l}<10 \\
<10\end{array}$ & $\begin{array}{l}<10 \\
<10\end{array}$ \\
\hline 5 & LE & $\mathrm{HM}$ & $20 / 30$ & Yes & Yes & $1,2,3$ & 2 & $>50$ & $10-24$ \\
\hline 6 & $\begin{array}{l}\mathrm{RE} \\
\mathrm{RE}\end{array}$ & $\begin{array}{l}20 / 40 \\
20 / 30\end{array}$ & $\begin{array}{l}20 / 20 \\
20 / 20\end{array}$ & $\begin{array}{l}\text { Yes } \\
\text { Yes }\end{array}$ & $\begin{array}{l}\text { No } \\
\text { No }\end{array}$ & $\begin{array}{l}2 \\
2,3\end{array}$ & $\begin{array}{l}- \\
-\end{array}$ & $\begin{array}{l}25-49 \\
25-49\end{array}$ & $\begin{array}{l}- \\
-\end{array}$ \\
\hline 7 & $\begin{array}{l}\text { LE } \\
\text { LE }\end{array}$ & $\begin{array}{l}N / L P \\
N / L P\end{array}$ & $\begin{array}{l}20 / 80 \\
20 / 100\end{array}$ & $\begin{array}{l}\text { Yes } \\
\text { Yes }\end{array}$ & $\begin{array}{l}\text { Yes } \\
\text { Yes }\end{array}$ & $\begin{array}{l}1,2,3 \\
1,2,3\end{array}$ & $\begin{array}{l}1 \\
1\end{array}$ & $\begin{array}{l}>50 \\
>50\end{array}$ & $\begin{array}{l}10-24 \\
10-24\end{array}$ \\
\hline 8 & LE & HM & CF $3 \mathrm{~m}$ & Yes & Yes & $1,2,3$ & $1,2,3$ & $>50$ & $>50$ \\
\hline 9 & $\begin{array}{l}\text { RE } \\
\text { LE }\end{array}$ & $\begin{array}{l}20 / 40 \\
20 / 100\end{array}$ & $\begin{array}{l}20 / 30 \\
20 / 25\end{array}$ & $\begin{array}{l}\text { Yes } \\
\text { Yes }\end{array}$ & $\begin{array}{l}\text { Yes } \\
\text { Yes }\end{array}$ & $\begin{array}{l}1,2,3 \\
1,2,3\end{array}$ & $\begin{array}{l}1 \\
1\end{array}$ & $\begin{array}{l}25-49 \\
25-49\end{array}$ & $\begin{array}{l}10-24 \\
10-24\end{array}$ \\
\hline 10 & $\begin{array}{l}\mathrm{LE} \\
\mathrm{LE}\end{array}$ & $\begin{array}{l}20 / 20 \\
20 / 20\end{array}$ & $\begin{array}{l}20 / 25 \\
20 / 30\end{array}$ & $\begin{array}{l}\text { No } \\
\text { No }\end{array}$ & $\begin{array}{l}\text { Yes } \\
\text { Yes }\end{array}$ & $\begin{array}{l}- \\
-\end{array}$ & $\begin{array}{l}2 \\
2\end{array}$ & $\begin{array}{l}- \\
-\end{array}$ & $\begin{array}{l}25-49 \\
25-49\end{array}$ \\
\hline 11 & $\begin{array}{l}\text { LE } \\
\text { RE }\end{array}$ & $\begin{array}{l}20 / 20 \\
20 / 20\end{array}$ & $\begin{array}{l}20 / 20 \\
20 / 60\end{array}$ & $\begin{array}{l}\text { Yes } \\
\text { Yes }\end{array}$ & $\begin{array}{l}\text { Yes } \\
\text { Yes }\end{array}$ & $\begin{array}{l}1 \\
1\end{array}$ & $\begin{array}{l}1 \\
1\end{array}$ & $\begin{array}{l}10-24 \\
10-24\end{array}$ & $\begin{array}{l}10-24 \\
10-24\end{array}$ \\
\hline 12 & RE & $20 / 40$ & $20 / 25$ & Yes & Yes & 1 & 1,2 & $10-24$ & $10-24$ \\
\hline 13 & $\mathrm{RE}$ & $20 / 20$ & $20 / 20$ & Yes & No & 1 & - & $<10$ & - \\
\hline 14 & $\begin{array}{l}\text { RE } \\
\text { LE }\end{array}$ & $\begin{array}{l}20 / 25 \\
20 / 80\end{array}$ & $\begin{array}{l}20 / 25 \\
20 / 25\end{array}$ & $\begin{array}{l}\text { Yes } \\
\text { Yes }\end{array}$ & $\begin{array}{l}\text { Yes } \\
\text { Yes }\end{array}$ & $\begin{array}{l}1 \\
1\end{array}$ & $\begin{array}{l}1 \\
1\end{array}$ & $\begin{array}{l}10-24 \\
10-24\end{array}$ & $\begin{array}{l}10-24 \\
10-24\end{array}$ \\
\hline 15 & $\begin{array}{l}\text { RE } \\
\text { LE }\end{array}$ & $\begin{array}{l}20 / 80 \\
20 / 60\end{array}$ & $\begin{array}{l}20 / 40 \\
20 / 40\end{array}$ & $\begin{array}{l}\text { Yes } \\
\text { Yes }\end{array}$ & $\begin{array}{l}\text { Yes } \\
\text { Yes }\end{array}$ & $\begin{array}{l}2,3 \\
2,3\end{array}$ & $\begin{array}{l}2,3 \\
2,3\end{array}$ & $\begin{array}{l}10-24 \\
10-24\end{array}$ & $\begin{array}{l}10-24 \\
10-24\end{array}$ \\
\hline 16 & RE & $20 / 60$ & LP & Yes & Yes & $1,2,3$ & $1,2,3$ & $25-49$ & $>50$ \\
\hline 17 & LE & CF $2 \mathrm{~m}$ & $20 / 80$ & Yes & Yes & $1,2,3$ & $1,2,3$ & $>50$ & $25-49$ \\
\hline 18 & LE & $\mathrm{N} / \mathrm{LP}$ & CF $3 \mathrm{~m}$ & Yes & Yes & $1,2,3$ & $1,2,3$ & $>50$ & $>50$ \\
\hline 19 & $\begin{array}{l}\text { LE } \\
\text { RE }\end{array}$ & $\begin{array}{l}20 / 60 \\
20 / 60\end{array}$ & $\begin{array}{l}20 / 20 \\
20 / 20\end{array}$ & $\begin{array}{l}\text { Yes } \\
\text { Yes }\end{array}$ & $\begin{array}{l}\text { Yes } \\
\text { Yes }\end{array}$ & $\begin{array}{l}1,2 \\
1,2\end{array}$ & $\begin{array}{l}2 \\
2\end{array}$ & $\begin{array}{l}10-24 \\
10-24\end{array}$ & $\begin{array}{l}10-24 \\
10-24\end{array}$ \\
\hline 20 & $\mathrm{RE}$ & $20 / 400$ & $20 / 20$ & Yes & No & 1 & - & $<10$ & - \\
\hline 21 & $\begin{array}{l}\text { LE } \\
\text { RE }\end{array}$ & $\begin{array}{l}20 / 40 \\
20 / 40\end{array}$ & $\begin{array}{l}20 / 60 \\
20 / 60\end{array}$ & $\begin{array}{l}\text { Yes } \\
\text { Yes }\end{array}$ & $\begin{array}{l}\text { Yes } \\
\text { Yes }\end{array}$ & $\begin{array}{l}2,3 \\
2,3\end{array}$ & $\begin{array}{l}2,3 \\
2,3\end{array}$ & $\begin{array}{l}25-49 \\
25-49\end{array}$ & $\begin{array}{l}25-49 \\
25-49\end{array}$ \\
\hline 22 & $\begin{array}{l}\text { RE } \\
\text { LE }\end{array}$ & $\begin{array}{l}20 / 30 \\
20 / 30\end{array}$ & $\begin{array}{l}20 / 20 \\
20 / 20\end{array}$ & $\begin{array}{l}\text { Yes } \\
\text { Yes }\end{array}$ & $\begin{array}{l}\text { Yes } \\
\text { Yes }\end{array}$ & $\begin{array}{l}1 \\
1\end{array}$ & $\begin{array}{l}3 \\
3\end{array}$ & $\begin{array}{l}10-24 \\
10-24\end{array}$ & $\begin{array}{l}<10 \\
<10\end{array}$ \\
\hline 23 & $\mathrm{RE}$ & $20 / 20$ & $20 / 20$ & Yes & No & 2 & - & $10-24$ & - \\
\hline 24 & LE & $20 / 30$ & $20 / 20$ & Yes & Yes & 1,2 & 1 & $25-49$ & $10-24$ \\
\hline 25 & LE & N/LP & CF $1 \mathrm{~m}$ & Yes & Yes & $1,2,3$ & $1,2,3$ & $>50$ & $>50$ \\
\hline 26 & $\begin{array}{l}\text { RE } \\
\text { LE }\end{array}$ & $\begin{array}{l}20 / 60 \\
20 / 60\end{array}$ & $\begin{array}{l}20 / 60 \\
20 / 30\end{array}$ & $\begin{array}{l}\text { Yes } \\
\text { Yes }\end{array}$ & $\begin{array}{l}\text { Yes } \\
\text { Yes }\end{array}$ & $\begin{array}{l}1,2 \\
1,2\end{array}$ & $\begin{array}{l}3 \\
3\end{array}$ & $\begin{array}{l}25-49 \\
25-49\end{array}$ & $\begin{array}{l}<10 \\
<10\end{array}$ \\
\hline
\end{tabular}


Table 2 - Patient, eye and pre-operative visual acuity, after 1 day, 1 month, final, and follow-up period (in months).

For abbreviations, see legend to Table 1.

\begin{tabular}{|c|c|c|c|c|c|c|}
\hline \multicolumn{2}{|c|}{ Patient/eye } & \multicolumn{4}{|c|}{ Visual acuity } & \multirow{2}{*}{$\begin{array}{l}\text { Follow-up } \\
\text { (months) }\end{array}$} \\
\hline & & \multirow{2}{*}{$\begin{array}{l}\text { Pre-op } \\
\text { CF } 1 \mathrm{~m}\end{array}$} & \multirow{2}{*}{$\begin{array}{l}\text { Day } 1 \\
\text { CF } 1 \text { m }\end{array}$} & \multirow{2}{*}{$\begin{array}{l}1 \text { month } \\
\text { CF } 1 \mathrm{~m}\end{array}$} & \multirow{2}{*}{$\begin{array}{c}\text { Final } \\
\text { CF } 1 \mathrm{~m}\end{array}$} & \\
\hline 1 & RE & & & & & 1 \\
\hline 2 & RE & $20 / 40$ & $20 / 25$ & $20 / 20$ & $20 / 400$ & 4 \\
\hline \multirow[t]{2}{*}{3} & LE & $20 / 20$ & $20 / 20$ & $20 / 60$ & $20 / 60$ & 2 \\
\hline & RE & $20 / 25$ & missed & $20 / 100$ & $20 / 100$ & 2 \\
\hline \multirow[t]{2}{*}{4} & LE & $20 / 25$ & $20 / 30$ & $20 / 30$ & $20 / 30$ & 4 \\
\hline & RE & $20 / 25$ & $20 / 40$ & $20 / 40$ & $20 / 40$ & 4 \\
\hline 5 & LE & $20 / 30$ & $20 / 25$ & $20 / 20$ & $20 / 20$ & 1 \\
\hline \multirow[t]{2}{*}{6} & $\mathrm{RE}$ & $20 / 40$ & $20 / 200$ & $20 / 40$ & $20 / 30$ & 8 \\
\hline & RE & $20 / 30$ & $20 / 25$ & $20 / 30$ & $20 / 25$ & 4 \\
\hline \multirow[t]{2}{*}{7} & LE & $20 / 80$ & $20 / 40$ & $20 / 30$ & $20 / 100$ & 8 \\
\hline & LE & $20 / 100$ & $20 / 100$ & $20 / 100$ & $20 / 100$ & 2 \\
\hline 8 & LE & CF $3 \mathrm{~m}$ & CF $3 \mathrm{~m}$ & CF $3 \mathrm{~m}$ & CF $3 \mathrm{~m}$ & 1 \\
\hline \multirow[t]{2}{*}{9} & RE & $20 / 40$ & $20 / 100$ & $20 / 20$ & $20 / 20$ & 6 \\
\hline & LE & $20 / 25$ & $20 / 25$ & $20 / 20$ & $20 / 20$ & 6 \\
\hline \multirow[t]{2}{*}{10} & LE & $20 / 25$ & $20 / 100$ & $20 / 30$ & $20 / 30$ & 9 \\
\hline & LE & $20 / 30$ & $20 / 25$ & $20 / 25$ & $20 / 25$ & 4 \\
\hline \multirow[t]{2}{*}{11} & LE & $20 / 20$ & $20 / 200$ & $\mathrm{HM}$ & $20 / 20$ & 7 \\
\hline & RE & $20 / 20$ & $20 / 20$ & $20 / 20$ & CF $3 \mathrm{~m}$ & 3 \\
\hline 12 & RE & $20 / 40$ & $20 / 60$ & $20 / 20$ & $20 / 20$ & 1 \\
\hline 13 & $\mathrm{RE}$ & $20 / 20$ & $20 / 40$ & $20 / 20$ & $20 / 20$ & 1 \\
\hline \multirow[t]{2}{*}{14} & $\mathrm{RE}$ & $20 / 25$ & $20 / 80$ & $20 / 20$ & $20 / 200$ & 4 \\
\hline & LE & $20 / 25$ & $20 / 60$ & $20 / 20$ & $20 / 20$ & 4 \\
\hline \multirow[t]{2}{*}{15} & $\mathrm{RE}$ & $20 / 80$ & $20 / 60$ & $20 / 40$ & $20 / 60$ & 5 \\
\hline & LE & $20 / 40$ & $20 / 40$ & $20 / 30$ & $20 / 25$ & 5 \\
\hline 16 & $\mathrm{RE}$ & $20 / 60$ & $20 / 100$ & $20 / 100$ & $20 / 100$ & 2 \\
\hline 17 & LE & $20 / 80$ & $20 / 80$ & $20 / 20$ & $20 / 40$ & 8 \\
\hline 18 & LE & CF $3 \mathrm{~m}$ & CF $3 \mathrm{~m}$ & CF $3 \mathrm{~m}$ & HM & 2 \\
\hline \multirow[t]{2}{*}{19} & LE & $20 / 20$ & $20 / 20$ & $20 / 20$ & $20 / 20$ & 4 \\
\hline & RE & $20 / 60$ & $20 / 100$ & $20 / 80$ & $20 / 60$ & 4 \\
\hline 20 & $\mathrm{RE}$ & $20 / 400$ & $20 / 400$ & $20 / 200$ & $20 / 200$ & 4 \\
\hline \multirow[t]{2}{*}{21} & LE & $20 / 60$ & $20 / 60$ & $20 / 200$ & $20 / 60$ & 1 \\
\hline & RE & $20 / 40$ & $20 / 80$ & $20 / 40$ & $20 / 40$ & 1 \\
\hline \multirow[t]{2}{*}{22} & $\mathrm{RE}$ & $20 / 30$ & $20 / 30$ & $20 / 30$ & $20 / 20$ & 4 \\
\hline & LE & $20 / 20$ & $20 / 25$ & $20 / 25$ & $20 / 20$ & 4 \\
\hline 23 & RE & $20 / 20$ & $20 / 50$ & $20 / 20$ & $20 / 20$ & 2 \\
\hline 24 & LE & $20 / 20$ & $20 / 60$ & $20 / 25$ & $20 / 20$ & 4 \\
\hline 25 & LE & CF $1 \mathrm{~m}$ & CF $2 \mathrm{~m}$ & CF $2 \mathrm{~m}$ & $N / L P$ & 2 \\
\hline \multirow[t]{2}{*}{26} & RE & $20 / 60$ & $20 / 60$ & $20 / 20$ & $20 / 70$ & 6 \\
\hline & LE & $20 / 25$ & $20 / 25$ & $20 / 20$ & $20 / 20$ & 5 \\
\hline
\end{tabular}

tenance doses of intravenous ganciclovir of $5 \mathrm{mg} \mathrm{kg}^{-1}$ day $^{-1}$ twice a week.

\section{Discussion}

CMV retinitis is one of the most important complications of AIDS, which can affect 6 to $38 \%$ of these patients and may be bilateral in 30 to $50 \%$ with up to $25 \%$ of the affected patients possibly losing their vision $(9,14)$. During the first decade of the epidemic, options for prophylaxis and treatment of CMV retinitis were very limited. During the last 5 years, several new treatment options have been studied and have proved to be efficient, safe and easy to administer.

The patients included in this study presented relapsing CMV retinitis, of difficult control by intravenous treatment. Before the implant, all patients had been submitted to at least one induction treatment with intravenous ganciclovir or foscarnet and were unsuccessfully receiving intravenous maintenance treatment with one of the two drugs. It is known that relapses may occur due to inadequate doses or frequency of injections or to marked immunodepression, since the virus remains latent in retinal cells. Usually they are manifested by the presence of an active border in the formerly healed lesion, suggesting that the predominant factor is the reactivation of the latent virus and not systemic reinfection.

In this study CMV retinitis healing was observed from the 15th day after surgery for implant placement and all patient had healed retinitis after the first postoperative month. Healing of the lesions was observed even in those patients with a suspicion of viral resistance to intravenous ganciclovir or foscarnet.

CMV retinitis relapse is common during maintenance therapy, occurring in approximately $85 \%$ of the patients. Mean recurrence time, evaluated by clinical observation, is 84 days for patients treated with intravenous ganciclovir, and 74 days for those treated 
with intravenous foscarnet (14). Anand et al. (33) analyzed the mean progression time for CMV retinitis in 30 eyes which received the intraocular ganciclovir implant and observed that this time was 19 weeks (133 days), a fact that confirms its advantage when compared with intravenous treatments. Mean progression time of CMV retinitis with an intraocular ganciclovir implant in patients with peripheral lesions and immediate treatment was 225 days as compared with 15 days in patients chosen for late treatment (35).

In the present study, 4 patients $(15.4 \%)$ developed CMV retinitis relapse. In two of them this relapse occurred during the eighth month (240 days), in one during the ninth month (270 days) and in the fourth, during the second month (60 days). The reasons why the fourth patient relapsed so early are unknown, but were probably related to the severity of ocular disease and the marked immunosuppression of this patient.

Marx et al. (37) in 1996 reported their experience with intraocular ganciclovir implants in patients with relapsing CMV retinitis. They treated 91 eyes of patients who had already been treated with an intravenous drug (ganciclovir or foscarnet). In the study by these authors, $76 \%$ of the patients responded to treatment with an intraocular implant within 1 month and $64 \%$ of them did not develop relapse during the study.

In the present study, $100 \%$ of the patients had their retinitis healed within the first month and only $15.4 \%$ suffered a relapse. This study included patients previously using intravenous ganciclovir and thus possibly presenting viral resistance, in contrast to other literature studies (38). Antiviral sensitivity was not determined. The high mortality at the time of this study did not allow observation of long-term results.

Ganciclovir implants present a series of advantages such as the presence of a constant drug level which may prevent viral replication during maintenance with subtherapeutic levels as well as viral resistance (39).
Patients presenting relapse or new lesions may receive another implant. Morley et al. (40) reported their experience with 9 eyes which received two or more implants after presenting relapse of the lesion, except for one patient who received the new implant after the seventh month due to an increase of the preexisting lesion. Patients who received the second implant in the same surgical incision as the first had the implant removed and the new one placed by the same surgical technique. Other patients received the implant in the upper quadrant or in the same quadrant, with an extension of the first incision. The authors concluded that multiple implants can be used without complications, with a good visual prognosis and control of CMV retinitis.

In the present study, 3 patients (11.5\%) who developed relapse of CMV retinitis received another implant using the same surgical technique. The second implant was placed in the inferior nasal quadrant. No patient presented ocular complications due to this procedure. The previously placed implants were not removed.

Retinal detachment in these patients may contribute to loss of vision. The rate of retinal detachment in patients with CMV retinitis may be 15 to $29 \%$ and the cumulative probability of this occurring one year after the diagnosis of retinitis is $50 \%$. Detachment may occur in the contralateral eye of 46 to $67 \%$ of the patients (14). Anand et al. (33), after treating 22 patients with intraocular implants, reported an $11 \%$ rate of retinal detachment which proved to be satisfactory when compared to the $29 \%$ rate attributed to previously reported viral action on the retina. Martin et al. (35) found an $18 \%$ rate of retinal detachment in CMV retinitis patients who received the intraocular implant as the first therapeutic modality.

In this study, $15.4 \%$ of the eyes developed retinal detachment. This rate is in agreement with former studies and with the percentage of retinal detachment due to the 
destructive action of the cytomegalovirus itself on the retina. There was no evidence that the implant could have increased the percentage of retinal detachment. The fact that these patients presented a longer period of exposure to the virus and several relapses, in addition to extensive retinal involvement, was also probably a risk factor.

In the present study, we chose to use posterior vitrectomy with silicone oil injection and endolaser application for those patients who developed retinal detachment. Results were good in $100 \%$ of the cases with retina application. The implant led to healing of retinitis in patients who had unsuccessfully received intravenous ganciclovir and foscarnet. Possible reasons include higher effectiveness of the local treatment with an adequate and stable level of the drug, eliminating the problem of compliance.

Some of the initially studied patients presented an already deteriorated ocular condition, probably with a short survival, and received the implant due to the lower risk of complications. The good result led to the use of the procedure even in patients with better vision. The initial experience reported in this study is in favor of the use of prolonged ganciclovir release ocular implants for the treatment of CMV retinitis in AIDS patients.

The HIV epidemic was the major event related to Medicine at the end of the 20th century. After twenty years of its impact, new diseases and clinical changes of associated diseases due to HIV have appeared. CMV retinitis is an outstanding example. Extremely rare before HIV, it became one of the most important ocular public health problems responsible for great morbidity, suffering and blindness. Fortunately the emergence of new antiretroviral and anti-CMV drugs has changed the situation, increasingly improving disease control.

Our data show that the surgical procedure for the placement of prolonged ganciclovir release ocular implants is simple and was not associated with clinically significant complications. The implant was shown to be efficient in preventing progression of CMV retinitis even in patients previously and unsuccessfully treated with intravenous drugs (ganciclovir or foscarnet) for periods of up to 8 months and to be a safe modality of local treatment.

\section{References}

1. Weiss RA (1993). How does HIV cause AIDS? Science, 260: 1273-1279.

2. Brasil. Ministério da Saúde. Programa Nacional de Doenças Sexualmente Transmissíveis/AIDS (1999). AIDS - Boletim Epidemiológico. Programa Nacional de Controle de Doenças Sexualmente Transmissíveis/AIDS.

3. Pollis MA \& Masur H (1995). Promising new treatments for cytomegalovirus retinitis. J ournal of the American Medical Association, 273: 1457-1459.

4. Centers for Disease Control (CDC) (1993). Revised classification system for HIV infection and expanded surveillance case definition for AIDS among adolescents and adults (1992). M orbidity and M ortality Weekly Report, 41: 1-19.

5. Bloom J N \& Nussenblatt RB (1988). The immunology of AIDS and the pathogen- esis of HIV infection. Ophthalmology Clinics of North America, 1: 15-29.

6. Holland GN, Pepose J S, Pettit TH, Gottlieb MS, Yee RD \& Foos RY (1983). Acquired immune deficiency syndrome: ocular manifestations. Ophthalmology, 90: 859873.

7. Hennis HL, Scott AA \& Apple DJ (1989). Cytomegalovirus retinitis. Survey of Ophthalmology, 34: 193-203.

8. England AC, Miller SA \& Maki DG (1982). Ocular findings of acute cytomegalovirus infection in an immunologically competent adult. New England J ournal of Medicine, 307: 94-95.

9. Friedman $A H$, Orellana J, Freeman WR, Luntz MH, Starr MB, Tapper ML, Spigland I, Roterdam H, Mesa Tejada R, Braunhut S \& Mildvan D (1983). Cytomegalovirus retinitis: a manifestation of the acquired immune deficiency syndrome (AIDS). British J ournal of Ophthalmology, 67: 372380.

10. Holland GN (1992). Acquired immunodeficiency syndrome and ophthalmology: The first decade. American J ournal of Ophthalmology, 114: 86-95.

11. Goodpasture EM \& Talbot FB (1921). Concerning the nature of "protozoan-like" cells in certain lesions of infancy. American J ournal of Diseases of Children, 21: 415-425.

12. Ho M (1991). Cytomegalovirus: Biology and Infection. 2nd edn. Plenum, New York.

13. Klemola E \& Kaariainen L (1965). Cytomegalovirus as a possible cause of a disease resembling infectious mononucleosis. British Medical J oumal, 5470: 1099-1102.

14. Holland GN, Tufail A \& J ordan MC (1996). 
Cytomegalovirus diseases. In: Pepose J S, Holland GN \& Wilhelmus KR (Editors), Ocular Infection and Immunity. Mosby, St. Louis, 1088-1129.

15. Holland GN, Gottlieb MS, Yee RD, Schanker HM \& Pettit TH (1982). Ocular disorders associated with a new severe acquired cellular immunodeficiency syndrome. American J ournal of Ophthalmology, 93: 393-402.

16. Freeman WR, Lerner CW, Mines J A, Lash RS, Nadel AJ, Starr MB \& Tapper ML (1984). A prospective study of the ophthalmologic findings in the acquired immune deficiency syndrome. American J ournal of Ophthalmology, 97: 133-142.

17. Palestine AG, Rodrigues MM, Macher AM, Chan CC, Lane HC, Fauci AS, Masur H, Longo G, Reichert CM \& Steis R (1984). Ophthalmic involvement in the acquired immunodeficiency syndrome. Ophthalmology, 91: 1092-1099.

18. Daicker B (1988). Cytomegalovirus panuveitis with infection of corneo-trabecular endothelium in AIDS. Ophthalmologica, 197: 169-175.

19. J abs DA, Enger C \& Bartlett J G (1989). Cytomegalovirus retinitis and acquired immunodeficiency syndrome. Archives of Ophthalmology, 107: 75-80.

20. Muccioli C, Belfort J $r$ R, Lottenberg $C$, Lima J, Santos P, Kim M, Abreu M \& Neves R (1994). Achados oftalmológicos em AIDS: avaliação de 445 casos, atendidos em 1 ano. Revista da Associação Médica Brasileira, 40: 155-158.

21. Nelson MR, Erskine D, Hawkins DA \& Gazzard G (1993). Treatment with corticosteroids - a risk factor for the development of clinical cytomegalovirus disease in AIDS. AIDS, 7: 375-378.

22. Pertel P, Hirschtick R, Phair J , Chmiel J, Poggensee $L \&$ Murphy R (1992). Risk of developing cytomegalovirus retinitis in persons infected with the human immunodeficiency virus. J ournal of Acquired Immunodeficiency Syndrome, 5: 10691074.

23. Muccioli $C$, Belfort J $r$ R, Podgor $M$, Sampaio $P$, Smet $M$ \& Nussenblatt $R$ (1996). Laser flare photometry in HIV-infected patients. Ocular Immunology and Inflammation, 4: 75-81.

24. Margolis TP, Lowder CY, Holland GN,
Spaide RF, Logan AG, Weissman SS, Invine AR, J osephberg $R$ \& Meisler DM (1991). Varicela-zoster virus retinitis in patients with the acquired immunodeficiency syndrome. American J ournal of Ophthalmology, 112: 119-131.

25. Pannuti CS, Kallás EG, Muccioli C, Roland RK, Ferreira EC, Bueno SMHS, Do Canto CLM, Villas Boas LS \& Belfort J r R (1996). Cytomegalovirus antigenemia in acquired immunodeficiency syndrome (AIDS) patients with untreated cytomegalovirus retinitis. American J ournal of Ophthalmology, 122: 847-852.

26. Yoser SL, Forster DJ \& Rao N (1993). Systemic viral infections and their retinal and choroidal manifestations. Survey of Ophthalmology, 37: 313-352.

27. Muccioli C, Petri V \& Belfort J r R (1996). Acquired immunodeficiency syndrome: ophthalmic and dermatologic manifestations. In: Mannis MJ , Macsai MS \& Huntley AC (Editors), Eye and Skin Disease. Lippincott-Raven, Philadelphia, 471-487.

28. Freeman WR, Quiceno JI, Crapotta JA, Listhaus $A$, Munguia $D \&$ Aguilar MF (1992). Surgical repair of rhegmatogenous retinal detachment in immunosuppressed patients with cytomegalovirus retinitis. Ophthalmology, 99: 466-474.

29. García RF, Flores-Aguilar M, Quiceno J I, Capparelli EV, Munguia D, Kuppermann BD, Arevalo F \& Freeman WR (1995). Results of rhegmatogenous retinal detachment repair in cytomegalovirus retinitis with and without scleral buckling. Ophthalmology, 102: 236-245.

30. Palestine AG, Stevens J r G, Lane HC, Masur H, Fujikawa LS, Nussenblatt RB, Rook AH, Manischewitz AS, Baird B, Megill M, Quinnan G, Gelmann E \& Fauci AS (1986). Treatment of cytomegalovirus retinitis with dihydroxy propoxymethyl guanine. American J oumal of Ophthalmology, 101: 95-101.

31. Studies of Ocular Complications of AIDS Research Group, in Collaboration with the AIDS Clinical Trials Group (1992). Mortality in patients with the acquired immunodeficiency syndrome treated with either foscarnet or ganciclovir for cytomegalovirus retinitis. New England J ournal of Medicine, 326: 213-220.

32. Smith TJ, Pearson PA, Blandford DL,
Brown J D, Goins KA, Hollins J L, Schmeisser ET, Glavinos P, Baldwin LB \& Ashton P (1992). Intravitreal sustained-release ganciclovir. Archives of Ophthalmology, 110: 255-258.

33. Anand R, Nightingale SD, Fish RH, Smith TJ \& Ashton P (1993). Control of cytomegalovirus retinitis using sustained-release of intraocular ganciclovir. Archives of Ophthalmology, 111: 223-227.

34. Anand R, Font RL, Fish RH \& Nightingale SD (1993). Pathology of cytomegalovirus retinitis treated with sustained release intravitreal ganciclovir. Ophthalmology, 100: 1032-1039.

35. Martin DF, Parks DJ, Mellow SD, Ferris FL, Walton RC, Remaley NA, Chew EY, Ashton P, Davis MD \& Nussenblatt RB (1994). Treatment of cytomegalovirus retinitis with an intraocular sustained-release ganciclovir implant: a randomized controlled clinical trial. Archives of Ophthalmology, 112: 1531-1539.

36. Holland GN, Buhles WC, Mastre B \& Kaplan HJ (1989). A controlled retrospective study of ganciclovir treatment for cytomegalovirus retinopathy. Use of a standardized system for the assessment of disease outcome. Archives of Ophthalmology, 107: 1759-1766.

37. Marx J L, Kapusta MA, Patel SS, La Bree LD, Walonker F, Rao NA \& Chong LP (1996). Use of the ganciclovir implant in the treatment of recurrent cytomegalovirus retinitis. Archives of Ophthalmology, 114: 815-820.

38. Sanborm GE, Anand R, Torti RE, Nightingale SD, Cal SX, Yates B, Ashton P \& Smith T (1992). Sustained-release ganciclovir therapy for treatment of cytomegalovirus retinitis: use of an intravitreal device. Archives of Ophthalmology, 110: 188-195.

39. Erice A, Chou S, Biron KK, Stanat SC \& Balfour J r HH (1989). Progressive disease due to ganciclovir-resistant cytomegalovirus in immunocompromised patients. New England J ournal of Medicine, 320: 289-293.

40. Morley MG, Duker J S, Ashton P \& Robinson MR (1995). Replacing ganciclovir implants. Ophthalmology, 102: 388392. 